\title{
VNITŘNÍ ZONÁLNOST TĚLES HORNIN TĚŠÍNITOVÉ ASOCIACE VE SLEZSKÉ JEDNOTCE: KORELACE PETROGRAFICKÝCH A PETROFYZIKÁLNÍCH PARAMETRŮ
}

\author{
Internal zonality of bodies of igneous rocks of teschenite association in the Silesian unit: \\ correlation of petrographic and petrophysical parameters \\ Kristýna Schuchová, Zdeněk Dolníček \\ Katedra geologie, Univerzita Palackého, třída 17. listopadu 12, 77146 Olomouc; e-mail: kristyna.schuchova@gmail.com
}

(25-21 Nový Jičín)

Key words: Silesian unit, igneous rocks of the teschenite association, microscopy, planimetry, magnetic susceptibility, density

\begin{abstract}
This article is focused on petrography of igneous rocks of the teschenite association and its correlation with selected petrophysical parameters. These igneous rocks were studied at three localities in the Silesian unit (Outer Western Carpathians) - Hodslavice, Žilina near Nový Jičín and Tichá. We conducted petrographic study (including modal composition based on planimetry) and then we compared results with previously published data on magnetic susceptibility and density of the same rock samples. The primary magmatic phases (clinopyroxenes, amphibole, biotite, opaque phases, feldspars and analcime) show in all cases less or more signs of post-magmatic alteration, giving rise mainly to secondary chlorite, carbonate and "limonite". The amount of chlorite ranges from 21 to 23, 3 to 9, and 16 to $35 \mathrm{mod}$. \% and those of carbonate vary from 5 to 15, 3 to 4, and 16 to 24 mod. \% in Hodslavice, Z̈ilina near Nový Jičin, and Tichá, respectively. The values of magnetic susceptibility range from $5.56 \times 10^{-8}$ to $7.66 \times 10^{-5}, 5.07 \times 10^{-7}$ to $1.61 \times 10^{-5}$, and $2.46 \times 10^{-7}$ to $2.93 \times 10^{-5}$ SI and those of density are between 2.50 and $2.77,2.66$ to 3.88 , and 2.65 to $2.86 \mathrm{~g} / \mathrm{cm}^{3}$ in Hodslavice, Žilina near Nový Jičín, and Tichá, respectively. Correlation of petrographic and petrophysical parameters suggests that various postmagmatic alterations (including chloritization, carbonatization and weathering associated with formation of limonite) can influence the values of magnetic susceptibility and density. The intensity of these alterations varies significantly among samples and sites.
\end{abstract}

Úvod

Horniny těšínitové asociace se vyskytují v hradišstském souvrství slezské jednotky (Eliáš 2003). Vyskytují se $\mathrm{v}$ pásu přes $100 \mathrm{~km}$ dlouhém, který se táhne od Hranic na Moravě až do oblasti Bielsko-Biala v Polsku (Dostal - Owen 1998). Těšínity byly datované radiometrickou metodou na polské straně Karpat, kde bylo stanoveno stárí $122,3 \pm 1,6 \mathrm{Ma}$ (Lucińska-Anczkiewicz et al. 2002; Grabowski et al. 2006).

Horniny těšínitové asociace vykazují velkou variabilitu v chemickém složení, ale také i ve vzájemných poměrech hlavních horninotvorných minerálů (Šmíd 1978; Matýsek 1992). Řada geologů se zabývala petrografií (Klvaňa 1897; Pacák 1926; Šmíd 1962; Kudělásková 1987; Kudělásková et al. 1993; Dolníček et al. 2010) a geochemií (Kudělásková 1987; Hovorka - Spišiak 1988; Matýsek 1992; Kudělásková et al. 1993; Dostal - Owen 1998; Dolníček et al. 2010; Buriánek - Bubík 2012) hornin těšínitové asociace. Horniny těšínitové asociace se obvykle dělí na těšínity, pikrity, bazalty a monchiquity (Hovorka - Spišiak 1988). V horninách těšínitové asociace se vyskytují hlavně tyto minerály: olivín, klinopyroxen (pyroxeny diopsid-hedenbergitové řady, augit, egirin), amfibol (kaersutit, ferrokaersutit), biotit, karbonát, apatit, analcim, magnetit, prehnit, titanit, minerály serpentinové skupiny, jílové minerály, chlorit či zeolity (Pacák 1926; Kudělásková 1987; Hovorka - Spišiak 1988; Dolníček et al. 2010; Buriánek - Bubík 2012). Těšínity sensu stricto jsou jemně až hrubě zrnité horniny. Jsou složeny převážně z bazického plagioklasu, klinopyroxenu, amfibolu, analcimu, apatitu a biotitu (Kudělásková 1987; Dolníček et al. 2010; Buriánek - Bubík 2012).

Článek se zabývá petrografickým složením hornin těšínitové asociace z vybraných lokalit ve slezské jednotce, kde byla již dřive studována magnetická susceptibilita (MS) a mineralogická hustota (Schuchová - Dolníček 2013), $s$ cílem pokusit se korelovat petrofyzikální parametry s poznatky petrografickými.

\section{Metodika}

Terénní výzkum proběhl v roce 2012 a zájmovými lokalitami byly Žilina u Nového Jič́na, Hodslavice a Tichá (bližší lokalizace viz Schuchová - Dolníček 2013). Dohromady bylo odebráno 22 vzorků (každý o hmotnosti přibližně $1 \mathrm{~kg}$ ) na př́ičných profilech přes tělesa magmatických hornin (Schuchová - Dolníček 2013). Makropopisy studovaných hornin jsou uvedeny v předešlém článku (Schuchová - Dolníček 2013). Pro následující petrografické studium se zhotovilo 7 zakrytých výbrusů. Z lokality v Hodslavicích a v Žilině u Nového Jičína se zhotovily dva výbrusy, zatímco z lokality Tiché se zhotovily výbrusy tř́i. Šlo o stejné vzorky, na nichž byly dříve studovány petrofyzikální vlastnosti (Schuchová - Dolníček 2013). Ve výbrusech se pozorovaly vzájemné vztahy mezi minerály, také četnost a intenzita různých přeměn (chloritizace, karbonatizace či limonitizace). Následně byla provedena planimetrie, aby se zjistilo procentuální zastoupení jednotlivých minerálů. Planimetr se posouval přibližně o $600 \mu \mathrm{m}$ s průměrným počtem 1770 bodů na jeden výbrus. 

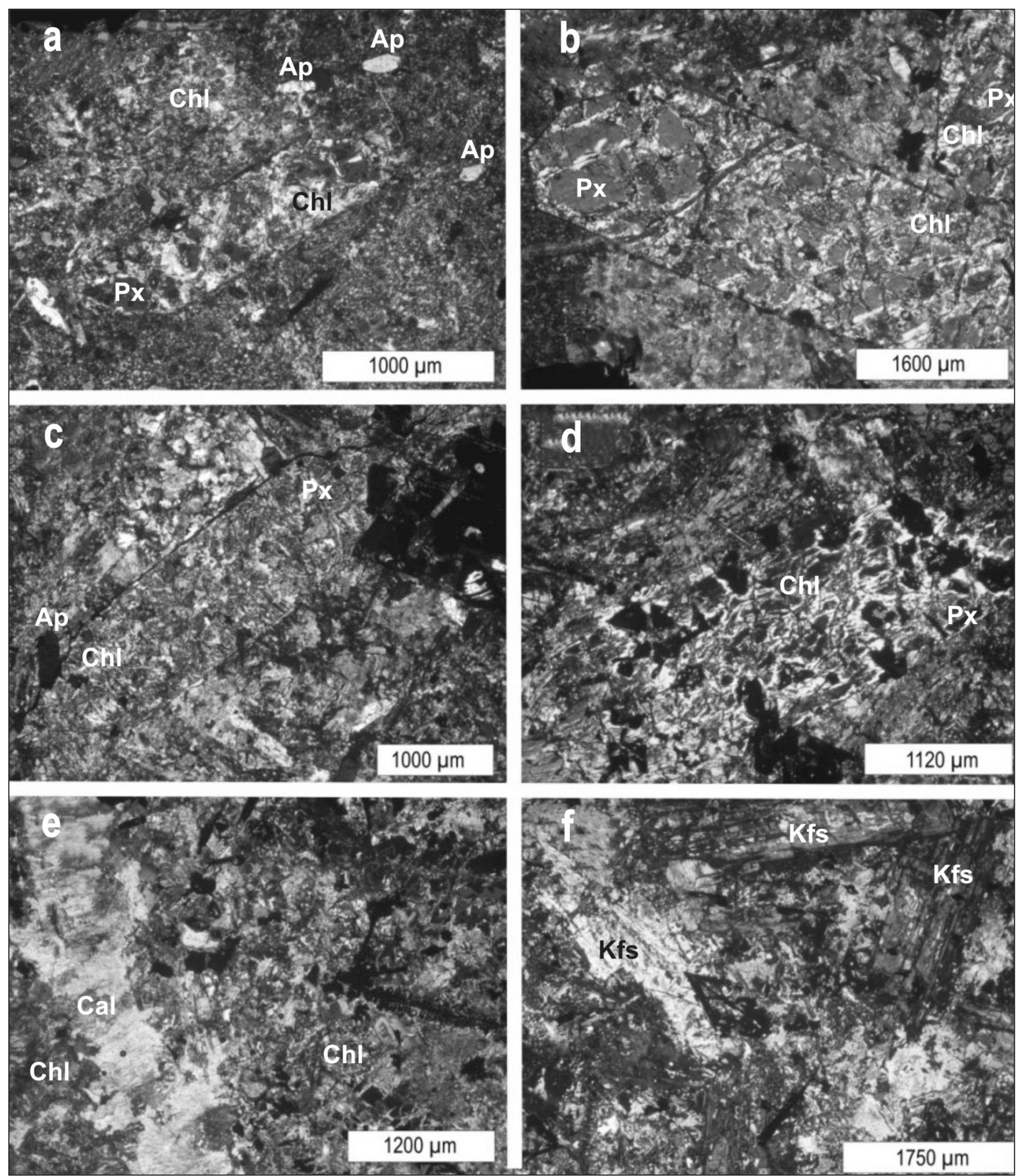

Obr. 1: Př́iklady alterací primárních minerálů ve studovaných vzorcích ve výbrusech: a - pokročilá chloritizace vyrostlice pyroxenu ve vzorku TICH13, zkřrižené nikoly (XPL); b - silná chloritizace vyrostlice pyroxenu ve vzorku TICH17 (XPL); c - velmi silná chloritizace vyrostlice pyroxenu ve vzorku TICH39,5 (XPL); d - silná chloritizace vyrostlice pyroxenu ve vzorku ZIL260 (XPL); e - pokročilá karbonatizace živců ve vzorku HOD150 (XPL); f - karbonatizace živců ve vzorku HOD310 (XPL).

Fig. 1: Examples of alteration of primary minerals in the studied samples in thin sections: a - advanced chloritization of pyroxene in the sample TICH13 (XPL); b - strong chloritization of pyroxene in the sample TICH17 (XPL); c - very strong chloritization of pyroxene in the sample TICH39,5 (XPL); $d$ - strong chloritization of pyroxene in the sample ZIL260 (XPL); e - advanced carbonatization of feldspars in the sample HOD150 (XPL); f - carbonatization of feldspars in the sample HOD310 (XPL).

\section{Výsledky petrografického studia \\ Hodslavice}

Zde byly zhotoveny dva výbrusy z hornin odebraných 150 a 310 cm od nadložního kontaktu ložní žíly s jílovými břidlicemi. Jedná se o vzorky HOD150 a HOD310.
Hornina (v literatuře popisovaná jako monchiquit; Matýsek 1988) je jemnozrnná a zrnitost se od nadloží k podloží neměnila. Horninu tvoří hlavně plagioklas, chlorit a karbonát o velikosti zrn 200-400 $\mu \mathrm{m}$. 
Zrna plagioklasů mají podlouhlý nebo nepravidelný tvar. V některých zrnech jsou uzavřena zrna opakních minerálů, chloritu či karbonátu. Plagioklasy často podléhají karbonatizaci (obr. 1e). Karbonatizace se projevovala jak na okrajích, tak i ve středech zrn a její intenzita se od vzorku HOD150 po vzorek HOD310 zvyšovala (5 a 15 mod. \%, tab. 1). Ve výbrusech byl $\mathrm{v}$ hojném množství přítomen i chlorit (21 a 23 mod. \%). Ve vzorku HOD150 byly vidět pseudomorfózy chloritu patrně po pyroxenech (původní minerál naprosto podlehl chloritizaci). Zrna apatitu mají jehličkovitý tvar a jsou uzavřena v zrnech živců a opakních minerálech. Ve vzorku HOD150 podléhají opakní minerály limonitizaci poněkud více než ve vzorku HOD310, kde jsou zrna postižena jen částečně. Planimetrie ukázala, že ve vzorku HOD150 je menší zastoupení opakních minerálů nežli ve vzorku HOD310 (tab. 1). Opakní minerály jsou kostrovitého nepravidelného tvaru, vzácněji mají jejich průřezy tvar lištovitý.

\section{Žilina u Nového Jičína}

$\mathrm{Z}$ této lokality se zhotovily dva výbrusy $\mathrm{z}$ hornin odebraných 70 a $260 \mathrm{~cm}$ od kontaktu s jílovými břidlicemi v nadloží. Jedná se o vzorky ZIL70 a ZIL260. Ve vzorku ZIL70 má hornina (pyroxenický těšínit) stejnoměrně zrnitou strukturu (průměrná velikost zrn je $200 \mu \mathrm{m}$ ), zatímco vzorek ZIL260 má strukturu porfyrickou.

Ve vzorku ZIL70 se nachází karbonát, chlorit, živec, analcim, pyroxeny (slabě nahnědlý nepleochroický augit s úhlem zhášení $33-43^{\circ}$, sytě zelený pleochroický egirinaugit/egirin), amfibol, biotit, apatit a opakní minerály. Základní hmotu horniny ve vzorku ZIL 260 tvoří karbonát, chlorit, živce, analcim, apatit a opakní fáze s velikostí zrn mezi $0,5-0,7 \mathrm{~mm}$. Vyrostlice tvoří pyroxen (velikost až 1,75 mm), amfibol (až 1,5 mm) a biotit (až 1,3 mm). Karbonát zatlačuje živce a analcim (obr. 1d). Po provedení planimetrie se ukázalo, že intenzita karbonatizace se směrem do podloží (od vzorku ZIL70 po ZIL260) postupně snižuje. Zastoupení karbonatizovaného analcimu se snižuje z 10 na 8 mod. \% a u karbonatizovaných živců se jedná o pokles ze 4 mod. \% na 3 mod. \% (tab. 1). Chlorit v obou výbrusech pseudomorfuje zrna pyroxenů (augitu). Chloritizace pyroxenů je nejsilnější ve vzorku ZIL70, kde jsou již všechna zrna zatlačena chloritem (pseudomorfózy zaujímají 3 mod. \%). Žádné zachovalé zrno nebo alespoň relikt pyroxenu se nenašly. Oproti tomu ve vzorku ZIL260 se vyskytuje větší množství zachovalých pyroxenů (6 mod. \%), které jsou chloritizací postiženy převážně při okrajích. Chloritizaci již podlehlo 9 mod. \% pyroxenu (tab. 1). Mimo augit se ve výbruse vyskytovala i zrna sytě zeleného egirinaugitu/egirinu, která narůstají na zrnech opakních minerálů, biotitu, amfibolu a augitu. Zrna amfibolu se vyskytovala pouze ve vzorku ZIL260. Amfiboly mají hnědou barvu, nepodléhají žádným přeměnám a mají úhel zhášení v rozmezí $11-24^{\circ}$. Místy je u některých zrn vidět magmatická koroze. Zrna biotitu mají tabulkovitý tvar a jsou bez přeměn. Zrna apatitu mají jehličkovitý tvar a často bývají uzavřena $\mathrm{v}$ opakních minerálech, biotitech, amfibolech, pyroxenech a v živcích. Opakní minerály jsou často zatlačovány „limonitem“. Ve vzorku ZIL70 takřka všechna zrna opakních minerálů podléhají limonitizaci. Jen místy se zde vyskytují zachovalá zrna. Ve vzorku ZIL260 podléhají opakní minerály jen částečně limonitizaci. Oproti tomu od vzorku ZIL70 k ZIL260 dochází k postupnému úbytku opakních minerálů z 18 mod. \% na 10 mod. \% (tab. 1).

\section{Tichá}

Z této lokality se zhotovily tři výbrusy a to $\mathrm{z}$ míst 13 , 17 a $39,5 \mathrm{~m}$ od začátku profilu (TICH13, TICH17 a TICH39,5). Struktura horniny (pyroxenického těšínitu; Dolníček et al. 2010) je porfyrická. Základní hmotu tvoří analcim, karbonát, chlorit a alkalické živce. Vyrostlice jsou tvořeny pyroxenem 
(velikost 1,6-2,2 mm; podle optických vlastností jde hlavně o augit, méně egirinaugit/egirin, srov. též Dolníček et al. 2010), amfibolem (velikost až $1,8 \mathrm{~mm}$ ), apatitem $(0,75 \mathrm{~mm})$, biotitem $(1,1 \mathrm{~mm})$, titanitem a opakními mi nerály $(0,6-1,1 \mathrm{~mm})$. V základní hmotě se také vyskytují zrna prehnitu, aragonitu či zeolitu.

Analcim tvoří převážnou část základní hmoty. Zrna analcimu jsou zakalená a podléhají karbonatizaci. Intenzita karbonatizace se zvyšuje s rostoucí vzdáleností od počátku profilu (pravděpodobně jde o podloží). Ve vzorku TICH13 je karbonatizace patrná převážně při okrajích zrn, vzácněji jí podléhají celá zrna. Ve vzorku TICH39,5 jsou takřka všechna zrna analcimu zatlačena karbonátem. Postupný nárůst intenzity karbonatizace analcimu byl doložen i planimetrickou analýzou. Množství karbonátu po analcimu se zvyšovalo z 16 na 24 mod. \% (tab. 1). Mimo analcim podléhají slabší karbonatizaci také i alkalické živce. Zrna alkalických živců mají nepravidelný nebo v jednom směru protáhlý tvar. Od TICH13 po TICH39,5 se množství zrn živců ve výbrusu zvyšuje (z 6 na 11 mod. \%). Ve výbrusech byl př́tomen i chlorit, který zatlačoval zrna augitu (obr. 1a, $1 \mathrm{~b}, 1 \mathrm{c})$. Intenzita chloritizace pyroxenů se postupně zvyšuje z 16 mod. \% až na 35 mod. \% (tab. 1). Ve vzorcích TICH13 a TICH17 jsou pyroxeny postiženy převážně při okrajích (vzácněji přeměně podléhají celá zrna), zatímco ve vzorku TICH39,5 jsou pyroxenová zrna zcela zatlačena chloritem. Egirinaugitová/egirinová zrna jsou bez přeměn a tvoři nárůsty na zrnech biotitu, opakních minerálech či augitu. Ve vzorcích TICH13 a TICH17 se vyskytl i hnědý amfibol (úhel zhášení $12-23^{\circ}$ ), zatímco ve vzorku TICH39,5 není př́tomen (tab. 1). Amfiboly nepodléhají žádným přeměnám. Zrna apatitu mají tence sloupcovitý nebo jehličkovitý tvar zrn. Bývají uzavřená v analcimu, biotitu, pyroxenu č v opakních minerálech. Biotit vytváří tabulkovitá, dlouze protáhlá zrna a je bez přeměn. Ve všech vzorcích je velmi častý výskyt opakních minerálů (až 7 mod. \% u vzorku TICH17). Zrna opakních minerálů postupně podléhají limonitizaci a karbonatizaci. U vzorku TICH13 je na zrnech opakních minerálů jen ojediněle patrná limonitizace. Ve vzorku TICH17 opakní minerály podléhají nejen limonitizaci, ale i karbonatizaci. U vzorku TICH39,5 je již většina zrn zatlačena limonitem a karbonátem. Opakní minerály v sobě uzavírají zrna apatitu, karbonátu, alkalických živců a chloritu. Narůstají na zrna biotitu a na zrna pyroxenu, která podléhají chloritizaci. Pouze u vzorku TICH39,5 bylo nalezeno zrno prehnitu, které se vyskytovalo v základní hmotě spolu s alkalickými živci. Vzácně se ve výbrusu vyskytovaly i relikty zeolitu, které se nacházely v blízkosti karbonátu.

\section{Diskuze \\ Hodslavice}

Horninové vzorky jsou tvořeny plagioklasem, karbonátem, apatitem a chloritem. Od nadloží (HOD150) do podloží (HOD310) docházelo ke snižování procentuálního zastoupení plagioklasu (37-16 mod. \%) a apatitu (2,0-0,4 mod. \%). Oproti tomu vzrůstalo zastoupení karbonátu (24-31 mod. \%) a chloritu (21-23 mod. \%). Mikroskopie neprokázala prrítomnost pyroxenu a amfibolu. Jen ve vzorku HOD150 byly vidět pseudomorfózy chloritu patrně po pyroxenu. Planimetrie také prokázala zvyšující se obsah opakních minerálů směrem do podloží - ve vzorku HOD150 bylo procentuální zastoupení opakních minerálů 9 mod. \%, zatímco ve vzorku HOD310 již bylo 15 mod. \%.

Opakní minerály podléhají limonitizaci více ve výbrusu HOD150 nežli v HOD310, což naznačuje pokročilejší alterace opakních minerálů směrem k nadloží. S tímto poznatkem korelují i hodnoty magnetické susceptibility (obr. 2a) a také hodnoty hustoty jsou vyšší ve vzorku HOD310 než ve vzorku HOD150 (obr. 3a).

Hodnoty magnetické susceptibility a hustoty se v Hodslavicích směrem k podloží zvyšovaly (Schuchová - Dolníček 2013). Autoři předpokládali rostoucí obsah feromagnetických či paramagnetických minerálů směrem do podloží (Schuchová - Dolníček 2013). Tento předpoklad byl výsledky provedené mikroskopie a planimetrie zčásti potvrzen, nebot' se zde směrem do podloží zvyšuje obsah feromagnetických minerálů a snižuje se obsah paramagnetických minerálů.

\section{Žilina u Nového Jičína}

Horninu tvoří karbonát, chlorit, živec, analcim, klinopyroxeny, amfibol, biotit, apatit a opakní minerály. Zrna analcimu a živců podléhají karbonatizaci a pyroxenová zrna zase chloritizaci. Od výbrusu ZIL70 k ZIL260 docházelo ke vzrůstu procentuálního zastoupení analcimu (0-7 mod. \%), živců (15-25 mod. \%), apatitu (1-3 mod. \%), pyroxenů (0-6 mod. \%) a amfibolů (0-5 \%). Vzrůst zastoupení paramagnetických minerálů (pyroxen, amfibol) částečně koreluje i se zvýšením hodnot magnetické susceptibility a hustoty (Schuchová - Dolníček 2013).

U opakních minerálů docházelo ke snižování jejich procentuálního zastoupení z 18 na 10 mod. \%, což může hodnoty magnetické susceptibility a hustoty snižovat. Z obrázků $2 \mathrm{a}$ a $3 \mathrm{a}$ je vidět, že vzrůstalo nejen procentuální zastoupení feromagnetických (opakní minerály) a paramagnetických minerálů (amfibol, pyroxen), ale také se zvyšovala hodnota magnetické susceptibility a hustoty.

Od ZIL70 k ZIL260 dochází ke snížení míry karbonatizace z 3,9 na 2,7 mod. \% a ke zvýšení hodnoty magnetické susceptibility a hustoty (obr. 2b, 3b).

Pyroxenová zrna v obou výbrusech silně podléhají chloritizaci. Ve vzorku ZIL70 podléhají chloritizaci více nežli ve vzorku ZIL260. U amfibolových zrn nedochází k žádným přeměnám. Hodnoty magnetické susceptibility a hustoty jsou u vzorku ZIL70 menší než u vzorku ZIL260 (Schuchová - Dolníček 2013).

\section{Tichá}

Ve všech vzorcích lze pozorovat postupné a mnohdy silné zatlačování pyroxenu chloritem a také limonitizaci opakních minerálů. Míra tohoto zatlačování se postupně od počátku profilu zvyšuje.

V TICH13 je nejnižší zastoupení opakních minerálů kolem 6 mod. \%, jež jen místy podléhají limonitizaci. Pyroxeny často podléhají chloritizaci nebo karbonatizaci. Procentuální zastoupení nepřeměněného pyroxenu je 9 mod. \%, zastoupení chloritu po pyroxenu je 16 mod. \% 

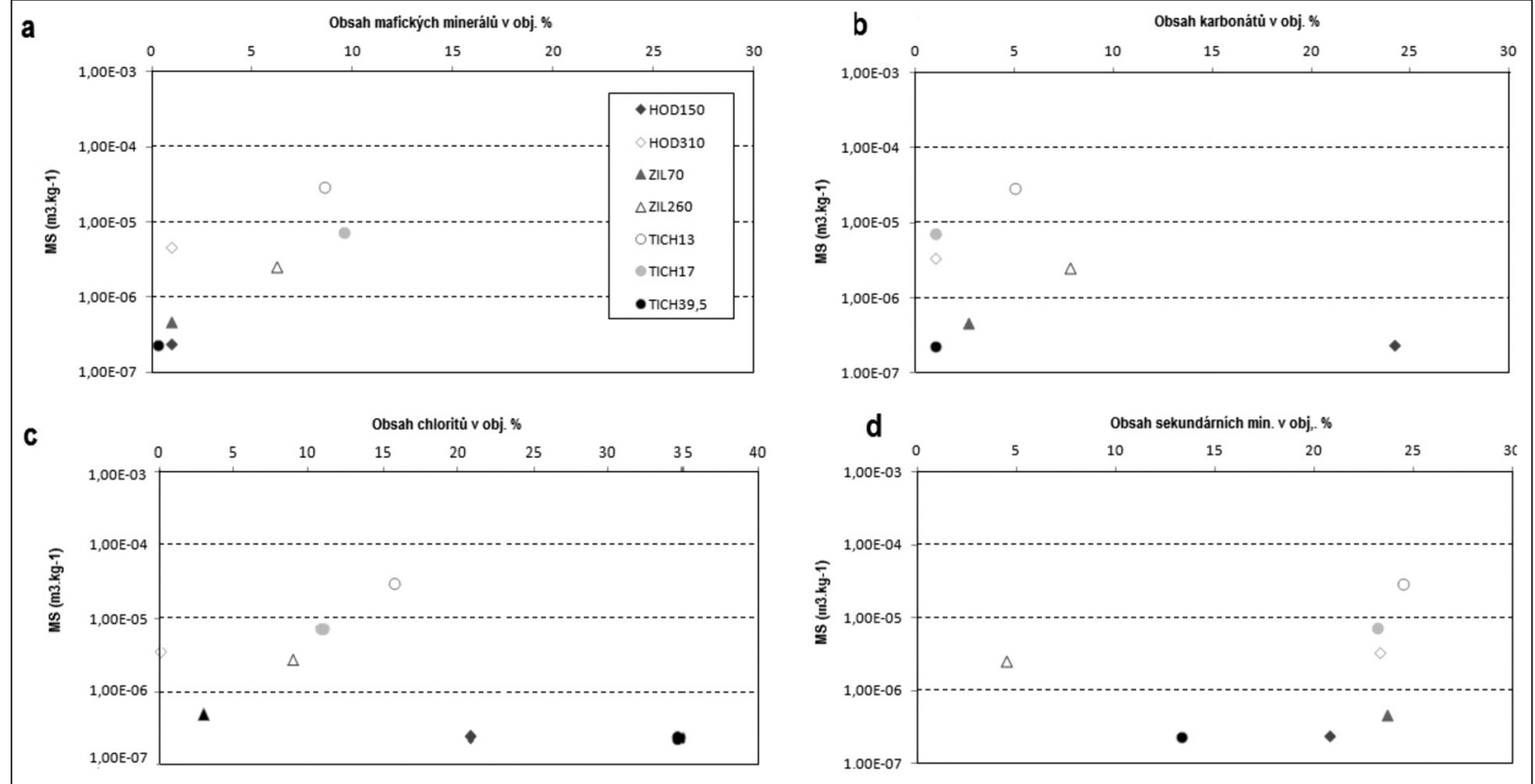

Obr. 2: Závislost hodnot magnetické susceptibility na výsledcích planimetrie: a - vztah MS a obsahu pyroxenu, amfibolu, biotitu a opakních minerálů v obj. \%; b - vztah MS a obsahu karbonátu (včetně karbonátu zatlačujícího pyroxeny, živce a analcim) v obj. \%; c - vztah MS a obsahu chloritu (včetně chloritu po pyroxenu) v obj. \%; d - vztah MS a obsahu sekundárních minerálních fází (chlorit, karbonát, živce a analcim) v obj. \%.

Fig. 2: Relationship between magnetic susceptibility (MS) and planimetry: a - relationship of MS and amount of pyroxene, amphibole, biotite, and opaque minerals in vol. \%; b - relationship of MS and amount of carbonate (including carbonate after pyroxene, feldspars, and analcime) in vol. \%; c - relationship of MS and amount of chlorite (including chlorite after pyroxene) in vol. \%; $\mathrm{d}$ - relationship of MS and amount of secondary phases (chlorite, carbonate, feldspars, and analcime) in vol. \%.
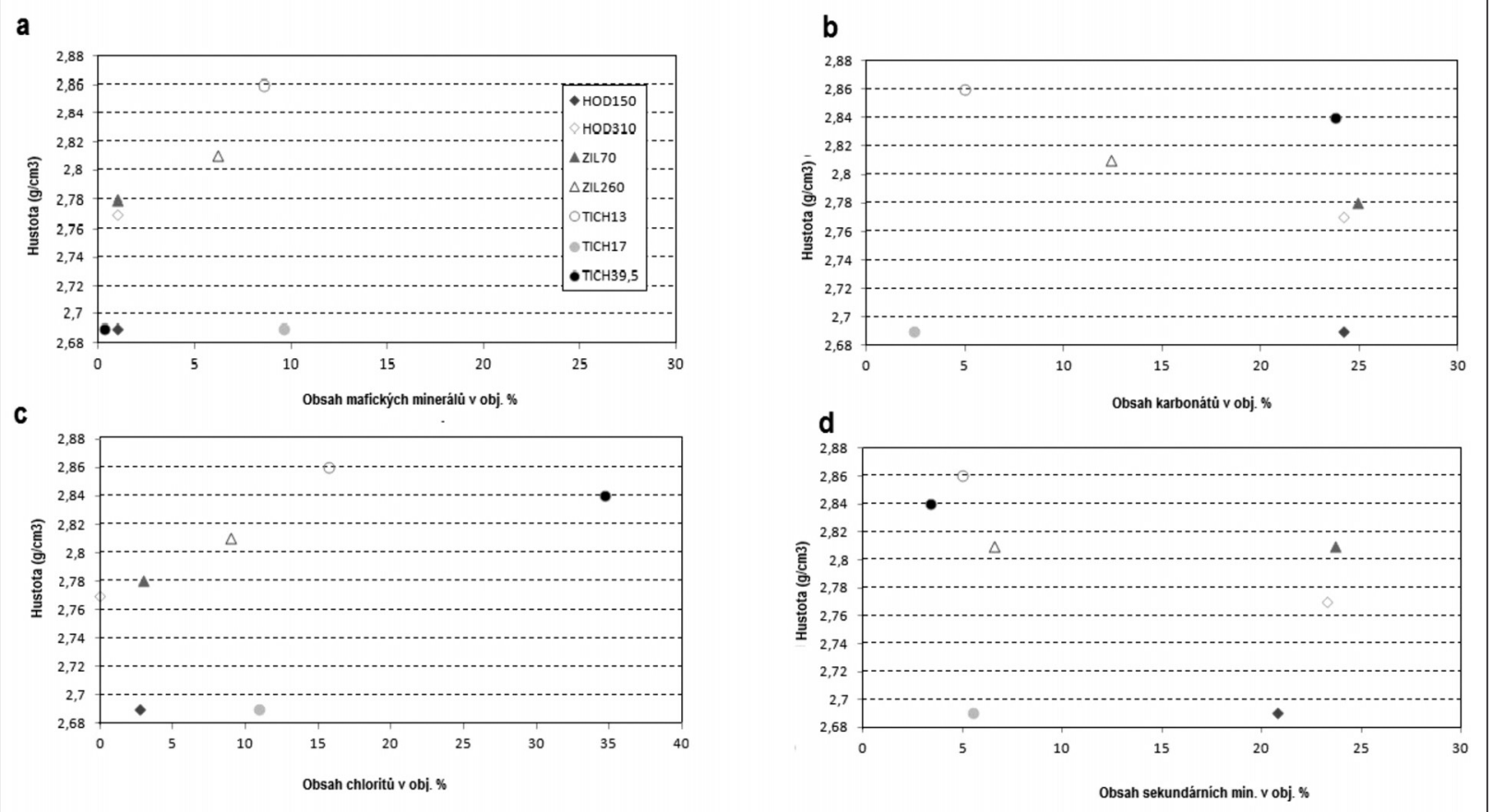

Obr. 3: Závislost hodnot mineralogické hustoty horninových vzorků na výsledcích planimetrie: a - vztah hustoty a obsahu pyroxenu, amfibolu, biotitu a opakních minerálů v obj. \%; b - vztah hustoty a obsahu karbonátu (včetně karbonátu po pyroxenu, živcích a analcimu) v obj. \%; c - vztah hustoty a obsahu chloritu (včetně chloritu po pyroxenu) v obj. \%; d - vztah hustoty a obsahu sekundárních fází (chlorit, karbonát, živce a analcim) v obj. \%.

Fig. 3: Relationship between rock density and planimetry: a - relationship of density and amount of pyroxene, amphibole, biotite, and opaque minerals in vol. \%; b - relationship of density and amount of carbonate (including carbonate after pyroxene, feldspars, and analcime) in vol. \%; c - relationship of density and amount of chlorite (including chlorite after pyroxene) in vol. \%; $\mathrm{d}$ - relationship of density and amount of secondary phases (chlorite, carbonate, feldspars, and analcime) in vol. \%. 
a karbonátu po pyroxenu 5 mod. \%. Na tomto vzorku byly naměřeny i vysoké hodnoty magnetické susceptibility a hustoty, které jsou způsobené vyšším obsahem feromagnetických (opakní minerály) a paramagnetických minerálů (amfibol, pyroxen) (Schuchová - Dolníček 2013). Je zde slabší alterace opakních minerálů oproti ostatním vzorkům.

Ve výbrusu TICH17 je zastoupení opakních minerálů 7 mod. \%. V tomto výbrusu opakní minerály podléhají nejen limonitizaci, ale i karbonatizaci. Oproti výbrusu TICH13 je zde vyšší procentuální zastoupení pyroxenů (10 mod. \%) a také méně pyroxenů podléhá chloritizaci (15 mod. \%) a karbonatizaci (2 mod. \%). Ačkoli je zde vyšší zastoupení pyroxenů a i vyšší zastoupení opakních minerálů, byly zde naměřeny razantně nižší hodnoty magnetické susceptibility a hustoty než u vzorku TICH13 (Schuchová - Dolníček 2013). Tak nízké hodnoty mohou být způsobeny intenzivnější alterací opakních minerálů.

V posledním vzorku (TICH39,5) již všechny minerály podléhají chloritizaci, karbonatizaci nebo limonitizaci. Zastoupení opakních minerálů je pouhých $3 \bmod$. \%. Limonitizaci podléhají $2 \%$ opakních minerálů. Všechna zrna pyroxenu úplně podlehla chloritizaci (35 mod. \%). $\mathrm{Na}$ tomto vzorku byla naměrena vysoká hodnota magnetické susceptibility a velmi nízká hodnota hustoty (Schuchová - Dolníček 2013). Z obrázků 2 a 3 je patrné, že se hodnoty magnetické susceptibility feromagnetických a paramagnetických minerálů postupně snižovaly, zatímco u chloritů, karbonátu či sekundárních minerálů byly naměřené kolísavé hodnoty.

Snižující se hodnoty magnetické susceptibility mohou být způsobené silnější limonitizací magnetických minerálů, také i snižující se hodnoty hustoty reflektují silnou chloritizaci, která naprosto pseudomorfovala zrna pyroxenů a limonitizaci.

\section{Závěr}

Mikroskopie a planimetrie na lokalitě Hodslavice Z větší části potvrzuje dřívější výsledky měření petrofyzikálních parametrů horninových vzorků odebraných z příčných profilů přes tělesa magmatických hornin, kde se od nadloží k podloží zvyšovala nejen magnetická susceptibilita, ale i hustota (Schuchová - Dolníček 2013). Od nadloží k podloží došlo k nárůstu zastoupení feromagnetických minerálů (opakní minerály) a spolu s tím se snižuje i intenzita jejich limonitizace.

V Žilině u Nového Jičína byly naměřeny kolísavé hodnoty magnetické susceptibility a hustoty (Schuchová - Dolníček 2013). Mikroskopie poukázala, že mnohé minerály často podléhají přeměnám (chloritizace analcimu a pyroxenu, karbonatizace živců, analcimu a pyroxenu, limonitizace opakních minerálů). Tyto přeměny mohou způsobovat kolísání hodnot magnetické susceptibility a hustoty (obr. 2 a 3 ).

Na lokalitě Tichá byly naměřeny také kolísavé hodnoty magnetické susceptibility a hustoty. Oproti vzorkům z lokality Žilina u Nového Jičína zde docházelo k mnohem razantnějším skokům hodnot petrofyzikálních parametrů. I zde minerály velmi hojně a silně podléhají přeměnám jako je chloritizace, limonitizace či karbonatizace. Také diagramy korelace mezi minerálním složením na jedné straně a magnetickou susceptibilitou či hustotou horninových vzorků na straně druhé poukazují na prudké skoky hodnot, které jsou způsobeny druhotnými přeměnami primárních minerálních fází.

\section{Poděkování}

Práce byla podpořena projektem IGA UP PrF-2014-019. Autoři děkují recenzentưm Z. Skácelové (ČGS Jeseník), D. Matýskovi (VŠB-TU Ostrava) a redaktorovi D. Buriánkovi (ČGS Brno) za připomínky a vstřícné posouzení rukopisu. 


\section{Literatura}

Buriánek, D. - Bubík, M. (2012): Horniny těšínitové asociace v okolí Valašského Meziříčí. - Acta Musei Moraviae, Scientia Geologicae, 97, 1, 89-111. Brno.

Dolníček, Z. - Kropáč, K. - Uher, P. - Polách, M. (2010): Mineralogical and geochemical evidence for multi-stage origin of mineral veins hosted by teschenites at Tichá, Outer Western Carpathians, Czech Republic. - Chemie der Erde, 70, 267-282.

Dostal, J. - Owen, V. (1998): Cretaceous alkaline lamprophyres from northeastern Czech Republic: geochemistry and petrogenesis. - Geologische Rundschau 87, 67-77.

Grabowski, J. - Krzemiński, L. - Nescieruk, P. - Starnawska, E. (2006): Paleomagnetism of the teschenitic rocks (Lower Cretaceous) in the Outer Western Carpathians of Poland: contraints for tectonic rotations in the Silesian unit. - Geophysical Instrument, 166, 1077-1094.

Hovorka, D. - Spišiak, J. (1988): Vulkanizmus mesozoika Západných Karpát. - Veda, Bratislava.

Klvaňa, J. (1897): Tešenity a pikrity na severovýchodní Moravě. - Nákladem České Akademie císaře Františka Josefa pro vědy, slovesnost a umění. Praha.

Kudělásková, M. (1987): Petrology and geochemistry of selected rock types of teschenite association, Outer Western Carpathians. - Geologica Carpathica, 38, 545-573.

Kudělásková, M. - Kudělásek, V. - Matýsek, D. (1993): Chemické a petrologické studium pikritových hornin z podbeskydské oblasti. - Sborník vědeckých prací Vysoké školy báňské v Ostravě, 39, 63-72. Ostrava.

Lucińska-Anczkiewicz, A. - Villa, I. M. - Anczkiewicz, R. - Ślaczka, A. (2002): ${ }^{40} \mathrm{Ar} /{ }^{39} \mathrm{Ar}$ dating of alkaline lamprophyres from the Polish Western Carpathians. - Geologica Carpathica. 53, 45-52.

Matýsek, D. (1988): Kontaktní metamorfismus hornin těšínitové asociace. - Časopis Slezského Muzea Opava (A), 37, 77-86.

Matýsek, D. (1992): Statistické vyhodnocení chemického složení pyroxenů a amfibolů hornin těšínitové asociace. - Časopis pro mineralogii a geologii, 37, 89-96, Praha.

Pacák, O. (1926): Sopečné horniny na úpatí Beskyd Moravských. - Rozpravy Československé akademie věd, 35. Praha.

Schuchová, K. - Dolníček, Z. (2013): Vnitřní zonálnost těles vyvřelých hornin těšínitové asociace ve slezské jednotce: petrofyzikální doklad. - Geologické výzkumy na Moravě a ve Slezsku, 20, 92-95. Brno.

Šmíd, B. (1962): Přehled geologie a petrografie hornin těšínitové asociace na severním úpatí Beskyd. - Geologické práce, 63, 53-60. Bratislava. 